\title{
STUDY OF FREQUENCY OF PATIENTS WITH HEREDITARY DISEASES IN GENERAL MEDICAL PRACTICE
}

\author{
V. Petrova-Tacheva ${ }^{1 *}$, B. Popov $^{1}$, S. Alekova ${ }^{2}$ \\ ${ }^{1}$ Department of Molecular Biology, Immunology and Medical Genetics, Faculty of Medicine \\ ${ }^{2}$ Department of General Medicine and Ophthalmology, Faculty of Medicine \\ Trakia University, Stara Zagora, Bulgaria
}

\begin{abstract}
In a patient registry of each family doctor found patients whose diseases are with a genetic nature. It determines the need for a wide range of knowledge and skills of general practitioners in the field of medical genetics, which will help them to early detection and diagnosis of these patients. In this regard, we set the goal to study of frequency of patients with diseases, which are hereditary in general medical practice. In more than half practices of the respondents to detect the presence of patients with diseases whose etio- pathogenesis has established a genetic relation. In the patient records of family physicians, these are mainly ill people with multifactorial, neuro-degenerative, cancer hereditary diseases, monogenic or chromosomal disorders, and also individuals with genetically determined mental retardation.
\end{abstract}

Key words: GPs, diseases with a genetic nature, frequency

\section{INTRODUCTION}

The recognition of the role of genetics factors in the causation of human disease has made clinical genetics one of the most rapidly developing fields in medicine. With the marked reduction in nutrition and infectious diseases in the developed countries, there has been an increasing awareness of the role of genetic determinants of human disease (1). The knowledge of medical genetics is important for today's health care practitioners because genetic diseases make up a large proportion of the total disease burden in both the pediatric and adult populations. In many cases this knowledge can lead to the actual prevention and more effective disease treatment (2). Achievements of medical genetics have important implications for clinical practice in various medical areas as obstetrics and gynecology, neonatology, pediatrics, endocrinology, hematology, oncology, general medical practice and other.

General practitioner is major figure in modern healthcare system in Bulgaria. He is placed at

\footnotetext{
*Correspondence to: Dr. Veselina PetrovaTacheva, Department of Molecular Biology, Immunology and Medical Genetics, Faculty of Medicine, Trakia University, 11 Armejska str, 6000 Stara Zagora, Tel.: 042/664311, Mobile: 0896056412,e-mail:vesepetr@abv.bg
}

bottom of the pyramid of the health system. In his ambulatory clinic GPs often meets with patients with suspected or proven hereditary diseases and predispositions, as monogenic diseases, congenital anomalies, socially significant multifactorial diseases and others. It determines the need for a wide range of knowledge and skills of general practitioners in the field of medical genetics, which will help them to early detection, accurate diagnosis and adequate treatment of these patients.

\section{PURPOSE}

The aims of the research were to determine and describe frequency and types of hereditary pathology in the general medical practices.

\section{MATERIALS AND METHODS}

It was conducted a detailed sociological survey of general practitioners from Stara Zagora region for the period of October 2013-April 2014. It was applied direct individual questionnaire in strict compliance with the principles of anonymity and voluntariness.

\section{RESULTS AND DISCUSSION}

The number of doctors, who fulfilled out the questionnaire carefully and responsibly, was 43. The most numerous of the age groups is the randing from 41 to 50 years $53,5 \%$. The number of registered patients for $39,5 \%$ of the general practitioners who participated in the 
survey is below 1000; for $27,9 \%$ of them is around 1000-1500 and for the remaining $32,6 \%$ is above 1500 .

A large percentage of respondents $(73,8 \%)$ said that they have patients with hereditary pathology in their general practices. With largest percentage among the groups of general practices with different total number of individuals with hereditary disorders are these with 11 to 20 patients with genetic disorders or without (Table 1).

Table 1. Distribution of the general medical practices according to the number of patients with hereditary pathology

\begin{tabular}{|c|c|c|}
\hline $\begin{array}{l}\text { Total number of patients } \\
\text { with hereditary pathology } \\
\text { in the general practice }\end{array}$ & $\begin{array}{l}\text { Number of the } \\
\text { general } \\
\text { practices }\end{array}$ & $\begin{array}{l}\text { Percentage of all } \\
\text { surveyed practices }\end{array}$ \\
\hline $\mathbf{0}$ & 11 & $25 \%$ \\
\hline $\mathbf{1}$ to $\mathbf{5}$ & 9 & $21 \%$ \\
\hline $\mathbf{6}$ to $\mathbf{1 0}$ & 5 & $12 \%$ \\
\hline $\mathbf{1 1}$ to $\mathbf{2 0}$ & 11 & $25 \%$ \\
\hline $\mathbf{2 1}$ to $\mathbf{4 0}$ & 2 & $5 \%$ \\
\hline over $\mathbf{4 0}$ & 5 & $12 \%$ \\
\hline
\end{tabular}

Genetically determined diseases are often classified into three major categories: chromosomal, single gene defects, and polygenic, or multifactorial, diseases. Recent studies on the molecular basis of human cancer require the addition of a fourth category, somatic cell genetic defects (1).

By definition, a chromosomal disorder is present if there is a visible alteration in the number or structure of the chromosomes. Using routine light microscopy and a moderate level of chromosome banding, the frequency of balanced and unbalanced structural rearrangements in newborns has been estimated at about 9,2 in 1000 (3). In our study we examined incidence of six chromosomal disorders (Table 2). The most common chromosomal disorder among surveyed patient registries is Down syndrome, which occurs in $30 \%$ of practices of the respondents. The total number of patients with Down syndrome, indicated from GPs is over 14. The number of individuals with Down syndrome in a practice is varied, but most often is 1 . Our results show that Turner Syndrome is occurs in $9,3 \%$ of the examined practices. Estimated total number of all individuals with monosomy $\mathrm{X}$ is 7 .

Table 2. Chromosomal disorders in general practices of the surveyed family doctors

\begin{tabular}{|l|c|c|}
\hline Cromosome disorders & $\begin{array}{c}\text { Number of the } \\
\text { clinical practices }\end{array}$ & $\begin{array}{c}\text { Percentage of all } \\
\text { surveyed practices }\end{array}$ \\
\hline Down Syndrome & 13 & $30 \%$ \\
\hline Turner Syndrome & 4 & $9,3 \%$ \\
\hline Klinefelter Syndrome & 1 & $2,3 \%$ \\
\hline Triple X Syndrome & 0 & $0 \%$ \\
\hline XYY Syndrome & 0 & $0 \%$ \\
\hline $\begin{array}{l}\text { CRI-DU-CHAT } \\
\text { Syndrome }\end{array}$ & 1 & $18,3 \%$ \\
\hline $\begin{array}{l}\text { Other chromosomal } \\
\text { disorders }\end{array}$ & 8 & $48,8 \%$ \\
\hline $\begin{array}{l}\text { Without chromosomal } \\
\text { disorders }\end{array}$ & 21 & \\
\hline
\end{tabular}

By definition, single gene disorders arise as result of mutations in one or both alleles of a gene on an autosome or sex chromosome or in a mitochondrial gene (3). In our study we examined the incidence of selected single-gene disorders in general practices of the surveyed family doctors (Table 3). Approximately of half of examined physicians answered that they have patients with inherited hemoglobin disorders. The total number of these patients, indicated from respondents is over 90. 
Table 3. Selected single-gene disorders in general practices of the surveyed GPs

\begin{tabular}{|c|c|c|}
\hline Single-gene dosorders & $\begin{array}{c}\text { Number of the } \\
\text { clinical practices }\end{array}$ & $\begin{array}{c}\text { Percentage of all } \\
\text { surveyed } \\
\text { practices }\end{array}$ \\
\hline Cystic fibrosis & 2 & $5 \%$ \\
\hline $\begin{array}{c}\text { Adult polycystic kidney } \\
\text { disease }\end{array}$ & 6 & $13,9 \%$ \\
\hline $\begin{array}{c}\text { Inherited hemoglobin } \\
\text { disorders }\end{array}$ & 20 & $46,5 \%$ \\
\hline Inborn errors of metabolism & 4 & $9,3 \%$ \\
\hline $\begin{array}{c}\text { Inherited immunodeficiency } \\
\text { diseases }\end{array}$ & 5 & $11,6 \%$ \\
\hline Other single-gene dosorders & 1 & $2,3 \%$ \\
\hline $\begin{array}{c}\text { Without single-gene } \\
\text { dosorders }\end{array}$ & 19 & $44,2 \%$ \\
\hline
\end{tabular}

Multifactorial disorders result from an interaction of one or more genes with one or more environmental factors. This, in effect, the genetic contribution predisposes the individuals to the actions of environmental factors (3). In our study we examined the incidence of hereditary pancreatitis, hereditary diabetes mellitus and hereditary thyrotoxicosis. Nearly $65 \%$ of the survey respondents said that they have patients with hereditary diabetes mellitus. The total number of the patients with hereditary diabetes mellitus is over 416 . The number of individuals vary from 1 to 50 as most often is 10 in a practice (Table 4).

Table 4. Selected multifactorial disorders in general practices of the surveyed family doctors

\begin{tabular}{|c|c|c|}
\hline $\begin{array}{c}\text { Selected multifactorial } \\
\text { disorders }\end{array}$ & $\begin{array}{c}\text { Number of the } \\
\text { clinical practices }\end{array}$ & $\begin{array}{c}\text { Percentage of all surveyed } \\
\text { practices }\end{array}$ \\
\hline Hereditary pancreatitis & 0 & $0 \%$ \\
\hline $\begin{array}{c}\text { Hereditary diabetes } \\
\text { mellitus }\end{array}$ & 28 & $65 \%$ \\
\hline $\begin{array}{c}\text { Hereditary } \\
\text { thyrotoxicosis }\end{array}$ & 11 & $25,5 \%$ \\
\hline $\begin{array}{c}\text { Others multifactorial } \\
\text { disorders }\end{array}$ & 1 & $2,3 \%$ \\
\hline $\begin{array}{c}\text { Without multifactorial } \\
\text { disorders }\end{array}$ & 14 & $32,6 \%$ \\
\hline
\end{tabular}

Over of half of surveyed family physicians said that they have patients with hereditary mental illness $(53,5 \%)$, with hereditary mental retardation $(53,5 \%)$ and with hereditary cancers $(51,2 \%)$ in their practices. Estimated total number of all individuals with hereditary mental illness is over 122 , with hereditary mental retardation is over 168 and with hereditary cancers is over 146 in all surveyed practices.

\section{CONCLUSION}

The hereditary pathology is widespread in general practice of family doctors.

General practitioners have a key role in prevention, early diagnosis and adequate treatment of these patients.
Genetic knowledge and skills are important to general practitioners providing support and management to patients with hereditary diseases.

\section{REFERENCES}

1. Gelehrter, T., Collins, F., Ginsburg, D, Principles of Medical Genetics. Lippincott Williams \& Wilkins, USA, pp 1-4, 1998

2. Jorde, L., Carey, J., Bamshad, M., White, R. Medical Genetics. Mosby, Inc, USA, pp 1-3, 2000

3. Rimoin, D., Pyeritz, R., Korf, B. Emery and Rimoin's Essential Medical Genetics. Elsevier Science \& Technology, UK, pp 1213, 2013 